\title{
Wildflower Tolerance to Metolachlor and Metolachlor Combined with Other Broadleaf Herbicides
}

\author{
Jeffrey F. Derr ${ }^{1}$ \\ Department of Plant Pathology, Physiology, and Weed Science, Virginia \\ Polytechnic Institute and State University, Hampton Roads Agricultural \\ Experiment Station, Virginia Beach, VA 23455
}

Additional index words. lanceleaf coreopsis, Coreopsis lanceolata, ox-eye daisy, Chrysanthemum leucantheum, purple coneflower, Echinacea purpurea, blanket flower, Gaillardia aristata, isoxaben, metolachlor, oxadiazon, simazine, preemergence herbicides, weed control

\begin{abstract}
The tolerance of transplanted lanceleaf coreopsis (Coreopsis lanceolata L.), ox-eye daisy (Chrysanthemum leucantheum L.), purple cone flower [Echinacea purpurea (L.) Moench.], and blanket flower (Gaillardia aristata Pursh) to metolachlor was determined in field trials. Metolachlor at $4.5 \mathrm{~kg} \cdot \mathrm{ha}^{-1}$ (maximum use rate) and $9.0 \mathrm{~kg} \cdot \mathrm{ha}^{-1}$ (twice the maximum use rate) did not reduce stand or flowering of any wildflower species after one or two applications, although plants developed transient visible injury. Combining metolachlor with the broadleaf herbicides simazine or isoxaben resulted in unacceptable injury and stand reduction, especially in ox-eye daisy. Metolachlor plus oxadiazon was less injurious to the wildflowers than metolachlor plus either simazine or isoxaben. Treatments containing metolachlor controlled yellow nutsedge (Cyperus esculentus L.) by at least $89 \%$ in both experiments. Treatments containing isoxaben controlled eclipta (Eclipta alba L.). 100\% in both studies. Chemical names used: $N$ - [3-(1-ethyl-1-methylpropyl)-5isoxazolyl]-2,6-dimethoxybenzamide (isoxaben); 2-chloro $-N$ - (2-ethyl-6-methylphenyl) $-N$ (2-methoxy-1-methylethyl)acetamide (metolachlor); 3-[2,4-di-chloro-5-(1methylethoxy)phenyl]-5-(1,1-dimethylethyl)-1,3,4-oxadiazol-2-(3 H) -one (oxadiazon); 6-chloro $-N, N^{\prime}$-diethyl-1,3,5-triazine-2,4-diamine (simazine).
\end{abstract}

There is considerable interest among the nursery and landscape industries in wildflowers and other herbaceous perennials. Wildflowers add color, diversity, and interest in low- and high-maintenance landscapes. Weed control is a major problem associated with

Received for publication 25 Mar. 1993. Accepted for publication 25 May 1993. The cost of publishing this paper was defrayed in part by the payment of page charges. Under postal regulations, this paper therefore must be hereby marked advertisement solely to indicate this fact.

'Associate Professor of Weed Science. time-consuming method to control weeds; thus, such methods would be limited in low-maintenance landscapes. When container nurseries were surveyed, hand-weeding costs ranged from $\$ 608$ to $\$ 1401 /$ ha, based on wages of $\$ 3.53$ to $\$ 3.97 / \mathrm{h}$ (Gilliam et al., 1990). Mulches can be used to suppress weed growth, but they generally will not control perennial weeds, such as yellow nutsedge (Derr and Appleton, 1992), and may become a good growing medium for weeds as they decompose. Chemical control is an alternative, economical method to control weeds in wildflower plantings.

Herbaceous perennials vary in their response to preemergence herbicides (Dickens, 1992; Porter, 1991). Isoxaben plus 4-(dipropylamino)-3,5-dinitrobenzene-sulfonamide (oryzalin) applied posttransplant caused moderate to severe injury to gloriosa daisy (Rudbeckia hirta L.) but did not injure lanceleaf coreopsis (Porter, 1991). In that study, isoxaben injured shasta daisy (Chrysanthemum maximum Ramond.) but not gloriosa daisy or lanceleaf coreopsis.

Metolachlor applied preemergence controls annual grasses, yellow nutsedge, and other common landscape weeds (Senesac and Neal, 1992). Metolachlor does not, however, control large-seeded broadleaf weeds. Simazine, isoxaben, and oxadiazon commonly are used in the nursery industry to control broadleaf weeds. The objective of this research was to determine the tolerance of lanceleaf coreopsis, ox-eye daisy, purple coneflower, and blanket flower to metolachlor. Combinations of metolachlor with simazine, isoxaben, and oxadiazon also were evaluated, since these combinations likely would control a broader weed spectrum than metolachlor alone.

\section{Materials and Methods}

General conditions. Lanceleaf coreopsis, ox-eye daisy, blanket flower, and purple coneflower were grown from seeds in a greenhouse using cell packs (cell size $6 \times 4 \times 5 \mathrm{~cm}$ ) that contained a commercial growing medium of sphagnum moss, vermiculite, and perlite (Pro-Mix BX, Premier Brands, Yonkers, N.Y.). Ten plants of each wildflower species were 
transplanted in each field plot. Plants were irrigated overhead after being transplanted. Plot size was $1.8 \times 6 \mathrm{~m}$. Each plot was fertilized with $710 \mathrm{~g}$ of a slow-release $17 \mathrm{~N}-2.6 \mathrm{P}-$ $9.9 \mathrm{~K}$ fertilizer that contained micronutrients (Osmocote 17-6-12; Grace-Sierra, Milpitas, Calif.). The experimental site contained a silt loam soil with a pH of 5.5 and $2.0 \%$ organic matter.

Herbicides were broadcast after transplanting using either a $\mathrm{CO}_{2}$-pressurized backpack sprayer calibrated to deliver 230 liters $\cdot h^{-1}$ or a shaker bottle for granular formulations. Treatments evaluated were a $5 \%$ granular formulation of metolachlor applied at 4.5 and 9.0 $\mathrm{kg} \cdot \mathrm{ha}^{-1}$ (maximum use rate and twice the maximum use rate, respectively), a $5 \%$ herbicide that contained $4 \%$ metolachlor and $1 \%$ simazine applied at 4.5 and $9.0 \mathrm{~kg} \cdot \mathrm{ha}^{-1}$, a dry flowable formulation of isoxaben at 0.8 and $1.1 \mathrm{~kg} \cdot \mathrm{ha}^{-1}$, a tank mix of isoxaben at 0.8 $\mathrm{kg} \cdot \mathrm{ha}^{-1}$ plus metolachlor at $4.5 \mathrm{~kg} \cdot \mathrm{ha}^{-1}$, and a granular formulation of metolachlor at 4.5 $\mathrm{kg} \cdot \mathrm{ha}^{-1}$ applied with a granular formulation of oxadiazon at 2.2 and $4.5 \mathrm{~kg} \cdot \mathrm{ha}^{-1}$. For the metolachlor plus oxadiazon treatments, the two granular herbicides were applied sepa- rately to the treated plots. Plots were irrigated overhead within $2 \mathrm{~h}$ after herbicides were applied. Herbicides were reapplied to the same plots the following year.

The design was a randomized complete block with four replications. Plots were rated visually for wildflower injury and weed control using a $0 \%$ to $100 \%$ scale, with $0 \%=$ no plants injured and $100 \%=$ all plants dead. The plot that contained the highest-quality plants in the study, regardless of treatment, was used as a reference for visual ratings; thus, wildflowers in the nontreated plots could receive a rating other than zero. Wildflower stand counts were determined after the first and second herbicide application by counting the surviving phantsaim each plot. Flower counts were taken at peak bloom. Results were subjected to analysis of variance and means were separated using the least significance difference procedure at $P \leq 0.05$.

1990-91 Study. Wildflowers were transplanted on 6 July 1990 and treated on 9 July 1990. Plant height at treatment was as follows: lanceleaf coreopsis, $14 \mathrm{~cm}$; ox-eye daisy, 5 $\mathrm{cm}$; purple coneflower, $10 \mathrm{~cm}$; and blanket flower, $9 \mathrm{~cm}$. The air was at $34 \mathrm{C}$ with no cloud cover. Wildflower injury was determined 2 and 9 weeks after treatment (WAT). Percent control of yellow nutsedge and eclipta was evaluated 7 WAT. Plant stand was recorded 9 WAT.

Herbicides were reapplied on 20 Mar. 1991. The air was at $17 \mathrm{C}$ and skies were partly cloudy. Plant stand was recorded 5 WAT (57 WAT with the first application). Ox-eye daisy and lanceleaf coreopsis flowers were counted 5 WAT and those of purple coneflower and blanket flower were counted 11 WAT.

1991-92 Study. The previous study was repeated in an adjacent field in 1991. Wildflower seedlings were transplanted on 29 May 1991. Herbicides were applied on 30 May 1991 under sunny skies, moist soil, and air at 37C. Plant height at treatment was 5.0 to 7.5 $\mathrm{cm}$ for all species.

Wildflowers were evaluated visually 4 and 6 WAT. Plant stand was determined 8 WAT. Yellow nutsedge control was recorded 6 WAT and eclipta control was determined 9 WAT. Blanket flower and purple coneflower flowers were counted 21 WAT.

Herbicides were reapplied on 10 Mar. 1992 under cloudy skies and air at 18C. Plant stands

Table 1. Percent injury to wildflower transplants 2 and 9 weeks after treatment (WAT) with preemergence herbicides, 1990-91.

\begin{tabular}{|c|c|c|c|c|c|c|c|c|c|}
\hline \multirow[b]{3}{*}{ Herbicide } & \multirow{3}{*}{$\begin{array}{c}\text { Rate } \\
\left(\mathrm{kg}^{\circ} \mathrm{ha}^{-1}\right)\end{array}$} & \multicolumn{8}{|c|}{ Plant injury (\%) } \\
\hline & & \multicolumn{2}{|c|}{$\begin{array}{l}\text { Lanceleaf } \\
\text { coreopsis }\end{array}$} & \multicolumn{2}{|c|}{$\begin{array}{l}\text { Ox-eye } \\
\text { daisy }\end{array}$} & \multicolumn{2}{|c|}{$\begin{array}{l}\text { Blanket } \\
\text { flower }\end{array}$} & \multicolumn{2}{|c|}{$\begin{array}{c}\text { Purple } \\
\text { coneflower }\end{array}$} \\
\hline & & $2 \mathrm{WAT}$ & 9 WAT & 2WAT & $9 \mathrm{WAT}$ & $2 \mathrm{WAT}$ & $9 \mathrm{WAT}$ & $2 \mathrm{WAT}$ & 9WAT \\
\hline Nontreated & & 2 & 8 & 2 & 4 & 7 & 13 & 5 & 6 \\
\hline \multirow[t]{2}{*}{ Metolachlor } & 4.5 & 1 & 9 & 10 & 10 & 11 & 15 & 10 & 13 \\
\hline & 9.0 & 0 & 5 & 12 & 8 & 2 & 11 & 10 & 21 \\
\hline \multirow{2}{*}{$\begin{array}{l}\text { Metolachlor } \\
+ \text { simazine }\end{array}$} & 3.6 & & & & & & & & \\
\hline & 0.9 & 17 & 13 & 55 & 13 & 25 & 14 & 35 & 14 \\
\hline \multirow{2}{*}{$\begin{array}{l}\text { Metolachlor } \\
+ \text { simazine }\end{array}$} & 7.2 & & & & & & & & \\
\hline & 1.8 & 25 & 20 & 77 & 15 & 42 & 18 & 35 & 11 \\
\hline \multirow[t]{2}{*}{ Isoxaben } & 0.8 & 2 & 5 & 80 & 100 & 40 & 13 & 10 & 9 \\
\hline & 1.1 & 7 & 9 & 47 & 40 & 32 & 18 & 17 & 14 \\
\hline \multirow{2}{*}{$\begin{array}{l}\text { Metolachlor } \\
+ \text { isoxaben }\end{array}$} & 4.5 & & & & & & & & \\
\hline & 0.8 & 12 & 9 & 65 & 71 & 25 & 15 & 32 & 23 \\
\hline \multirow{2}{*}{$\begin{array}{l}\text { Metolachlor } \\
+ \text { oxadiazon }\end{array}$} & 4.5 & & & & & & & & \\
\hline & 2.2 & 5 & 5 & 20 & 8 & 17 & 11 & 22 & 20 \\
\hline \multirow{2}{*}{$\begin{array}{l}\text { Metolachlor } \\
\text { + oxadiazon }\end{array}$} & 4.5 & & & & & & & & \\
\hline & 4.5 & 3 & 6 & 6 & 6 & 5 & 6 & 17 & 14 \\
\hline $\operatorname{LSD}_{(0.05)}$ & & 9 & 9 & 22 & 29 & 18 & 12 & 20 & 15 \\
\hline
\end{tabular}

Table 2. Percent injury to wildflower transplants 4 and 6 weeks after treatment (WAT) with preemergence herbicides, 1991-92.

\begin{tabular}{|c|c|c|c|c|c|c|c|c|c|}
\hline \multirow[b]{3}{*}{ Herbicide } & \multirow{3}{*}{$\begin{array}{c}\text { Rate } \\
\left(\mathrm{kg} \cdot \mathrm{ha}^{-1}\right)\end{array}$} & \multicolumn{8}{|c|}{ Plant injury (\%) } \\
\hline & & \multicolumn{2}{|c|}{$\begin{array}{l}\text { Lanceleaf } \\
\text { coreopsis }\end{array}$} & \multicolumn{2}{|c|}{$\begin{array}{c}\text { Ox-eye } \\
\text { daisy }\end{array}$} & \multicolumn{2}{|c|}{$\begin{array}{l}\text { Blanket } \\
\text { flower }\end{array}$} & \multicolumn{2}{|c|}{$\begin{array}{c}\text { Purple } \\
\text { coneflower }\end{array}$} \\
\hline & & 4 WAT & 6 WAT & 4 WAT & $6 \mathrm{WAT}$ & 4 WAT & $6 \mathrm{WAT}$ & 4 WAT & 6 WAT \\
\hline Nontreated & & 0 & 0 & 0 & 0 & 0 & 0 & 0 & 0 \\
\hline \multirow[t]{2}{*}{ Metolachlor } & 4.5 & 8 & 4 & 15 & 18 & 28 & 23 & 20 & 23 \\
\hline & 9.0 & 18 & 14 & 23 & 23 & 40 & 30 & 25 & 30 \\
\hline \multirow{2}{*}{$\begin{array}{l}\text { Metolachlor } \\
\text { + simazine }\end{array}$} & 3.6 & & & & & & & & \\
\hline & 0.9 & 73 & 33 & 90 & 85 & 85 & 65 & 95 & 65 \\
\hline \multirow{2}{*}{$\begin{array}{l}\text { Metolachlor } \\
\text { + simazine }\end{array}$} & 7.2 & & & & & & & & \\
\hline & 1.8 & 93 & 83 & 100 & 100 & 100 & 100 & 100 & 100 \\
\hline \multirow[t]{2}{*}{ Isoxaben } & 0.8 & 55 & 43 & 88 & 85 & 73 & 55 & 35 & 55 \\
\hline & 1.1 & 53 & 38 & 100 & 100 & 70 & 45 & 38 & 45 \\
\hline Metolachlor & 4.5 & & & & & & & & \\
\hline + isoxaben & 0.8 & 43 & 38 & 93 & 80 & 73 & 45 & 50 & 45 \\
\hline Metolachlor & 4.5 & & & & & & & & \\
\hline + oxadiazon & 2.2 & 8 & 8 & 16 & 18 & 38 & 25 & 38 & 25 \\
\hline Metolachlor & 4.5 & & & & & & & & \\
\hline + oxadiazon & 4.5 & 10 & 6 & 29 & 30 & 35 & 25 & 50 & 25 \\
\hline $\operatorname{LSD}_{(0.05)}$ & & 19 & 18 & 18 & 23 & 23 & 23 & 16 & 19 \\
\hline
\end{tabular}


were recorded 8 WAT (47 WAT with the first application). Ox-eye daisy and coreopsis flowers were counted 8 WAT.

\section{Results and Discussion}

Little or no injury to any of the wildflowers was observed following metolachlor application at either rate in the 1990-91 study (Table 1 ). The higher rate of metolachlor plus simazine was the only treatment that injured lanceleaf coreopsis on both dates in the 199091 study. Treatments that contained simazine or isoxaben caused moderate to severe injury to ox-eye daisy but less injury to blanket flower and purple coneflower. Metolachlor plus oxadiazon caused less injury to wildflowers than metolachlor plus either simazine or isoxaben.

The injury observed in ox-eye daisy after isoxaben was applied is consistent with that reported in shasta daisy, another Chrysanthemum species, from isoxaben (Porter, 1991). Oxadiazon alone did not damage lanceleaf coreopsis or shasta daisy (Skroch et al., 1990), a result that may explain the lower injury induced by metolachlor plus oxadiazon compared to metolachlor plus isoxaben. Oxadiazon has injured other herbaceous perennials, however, such as liriope [Liriope muscari (Decne) L.H. Bailey], when applied at $4.5 \mathrm{~kg} \cdot \mathrm{ha}^{-1}$, with less injury observed at $2.2 \mathrm{~kg} \cdot \mathrm{ha}^{-1}$ (Glaze, 1987), or daylily (Hemerocallus $\times$ 'Aztec Gold'), which outgrew the damage (Norcini and Aldrich, 1992).

Wildflowers were injured more severely in the 1991-92 study (Table 2), perhaps due to higher temperatures soon after planting, a condition that caused additional plant stress, or herbicide leaching from more-frequent irrigation. In the week before planting, total rainfall was $26 \mathrm{~mm}$ for the 1990-91 study but only 1 $\mathrm{mm}$ in the 1991-92 study. In the 1990-91 study, the average high temperature for the first 3 days of the study was 30C, with a total rainfall of $13 \mathrm{~mm}$; in the 1991-92 study, the average high temperature for the first three days was $35 \mathrm{C}$, with no rain. The higher rate of metolachlor caused moderate (15\% to $40 \%$ ) injury to the wildflowers, with slightly less injury at the lower rate. Metolachlor plus simazine caused severe injury to all species and completely killed all species except lanceleaf coreopsis at the higher rate. Isoxaben severely injured all species and completely killed ox-eye daisy at the higher rate. As in the first study, metolachlor plus oxadiazon was less phytotoxic than metolachlor plus either simazine or isoxaben.

No herbicide reduced stands of lanceleaf coreopsis, blanket flower, or purple coneflower after one or two applications in the 1990-91 study (Table 3 ). Treatments that contained simazine or isoxaben reduced ox-eye daisy stands, a result consistent with the injury observed earlier (Table 1).

Metolachlor applied alone or with oxadiazon did not affect the survival of any wildflower species in the 1991-92 study (Table 4). Metolachlor plus simazine reduced the stand of all four species, while metolachlor plus isoxaben reduced stands of ox-eye daisy and blanket flower.

No herbicide reduced flower production of lanceleaf coreopsis, blanket flower, or purple

Table 3. Wildflower stand per plot 9 weeks after treatment (WAT) with the first preemergence herbicide application and 57 WAT with the initial application (5 WAT with the second herbicide application), 1991-92.

\begin{tabular}{|c|c|c|c|c|c|c|c|c|c|}
\hline \multirow[b]{3}{*}{ Herbicide } & \multirow{3}{*}{$\begin{array}{c}\text { Rate } \\
\left(\mathrm{kg}^{\prime} \mathrm{ha}^{-1}\right)\end{array}$} & \multicolumn{8}{|c|}{ No./plot } \\
\hline & & \multicolumn{2}{|c|}{$\begin{array}{l}\text { Lanceleaf } \\
\text { corcopsis }\end{array}$} & \multicolumn{2}{|c|}{$\begin{array}{l}\text { Ox-eye } \\
\text { daisy }\end{array}$} & \multicolumn{2}{|c|}{$\begin{array}{l}\text { Blanket } \\
\text { flowcr }\end{array}$} & \multicolumn{2}{|c|}{$\begin{array}{c}\text { Purple } \\
\text { coneflower }\end{array}$} \\
\hline & & $9 \mathrm{WAT}$ & $57 \overline{\mathrm{WAT}}$ & 9 WAT & $57 \mathrm{WAT}$ & 9 WAT & 57 WAT & $9 \mathrm{WAT}$ & 57 WAT \\
\hline Nontreated & & 9.8 & 9.3 & 8.5 & 8.3 & 7.5 & 6.8 & 8.3 & 7.5 \\
\hline Metolachlor & 4.5 & 9.8 & 9.8 & 7.5 & 8.0 & 9.0 & 8.0 & 8.5 & 8.3 \\
\hline & 9.0 & 10.0 & 10.0 & 6.8 & 6.5 & 9.8 & 9.8 & 7.5 & 8.0 \\
\hline Metolachlor & 3.6 & & & & & & & & \\
\hline+ simazine & 0.9 & 9.8 & 9.8 & 4.0 & 4.3 & 8.5 & 9.3 & 6.3 & 6.0 \\
\hline Metolachlor & 7.2 & & & & & & & & \\
\hline+ simazine & 1.8 & 9.3 & 9.3 & 1.3 & 1.3 & 7.0 & 7.3 & 6.5 & 5.8 \\
\hline Isuxaben & 0.8 & 9.8 & 10.0 & 0.0 & 0.0 & 7.8 & 7.5 & 8.0 & 8.5 \\
\hline & 1.1 & 10.0 & 10.0 & 1.3 & 1.3 & 7.3 & 7.0 & 7.0 & 6.5 \\
\hline Metolachlor & 4.5 & & & & & & & & \\
\hline + isoxaben & 0.8 & 9.8 & 9.8 & 0.5 & 0.5 & 8.8 & 8.5 & 6.3 & 5.5 \\
\hline Metolachlor & 4.5 & & & & & & & & \\
\hline + oxadiazon & 2.2 & 9.8 & 10.0 & 7.3 & 7.5 & 9.0 & 8.5 & 7.0 & 6.5 \\
\hline Metolachlor & 4.5 & & & & & & & & \\
\hline + oxadiazon & 4.5 & 9.8 & 9.8 & 8.8 & 9.5 & 9.8 & 10.0 & 8.8 & 8.0 \\
\hline $\operatorname{LSD}_{(0.05)}$ & & 0.9 & 0.9 & 2.2 & 2.2 & 2.7 & 2.6 & 3.0 & 2.9 \\
\hline
\end{tabular}

Table 4. Wildflower stand per plot 6 weeks after treatment (WAT) with the first preemergence herbicide application and 53 WAT with the initial application (8 WAT with the second herbicide application), 1991-92

\begin{tabular}{|c|c|c|c|c|c|c|c|c|c|}
\hline \multirow[b]{3}{*}{ Herbicide } & \multirow{3}{*}{$\begin{array}{c}\text { Rate } \\
\left(\mathrm{kg}^{2} \cdot \mathrm{ha}^{-1}\right)\end{array}$} & \multicolumn{8}{|c|}{ No./plot } \\
\hline & & \multicolumn{2}{|c|}{$\begin{array}{l}\text { Lanceleaf } \\
\text { coreopsis }\end{array}$} & \multicolumn{2}{|c|}{$\begin{array}{l}\text { Ox-eye } \\
\text { daisy }\end{array}$} & \multicolumn{2}{|c|}{$\begin{array}{l}\text { Blanket } \\
\text { flower }\end{array}$} & \multicolumn{2}{|c|}{$\begin{array}{c}\text { Purple } \\
\text { coneflower }\end{array}$} \\
\hline & & $6 \overline{\mathrm{WAT}}$ & $53 \mathrm{WAT}$ & 6WAT & $53 \mathrm{WAT}$ & $6 \mathrm{WAT}$ & 53 WAT & 6WAT & $53 \mathrm{WAT}$ \\
\hline Nontreated & & 10.0 & 8.3 & 10.0 & 3.5 & 8.8 & 5.8 & 10.0 & 8.0 \\
\hline \multirow[t]{2}{*}{ Metolachlor } & 4.5 & 10.0 & 9.8 & 10.0 & 8.0 & 9.0 & 8.0 & 10.0 & 8.3 \\
\hline & 9.0 & 10.0 & 9.3 & 10.0 & 10.0 & 6.8 & 6.5 & 9.5 & 7.3 \\
\hline \multirow{2}{*}{$\begin{array}{l}\text { Metolachlor } \\
\text { + simazine }\end{array}$} & 3.6 & & & & & & & & \\
\hline & 0.9 & 4.0 & 3.5 & 1.3 & 1.3 & 3.0 & 3.3 & 0.8 & 0.8 \\
\hline \multirow{2}{*}{$\begin{array}{l}\text { Metolachlor } \\
+ \text { simazine }\end{array}$} & 7.2 & & & & & & & & \\
\hline & 1.8 & 0.8 & 0.3 & 0.0 & 0.3 & 0.3 & 0.8 & 0.0 & 0.0 \\
\hline \multirow[t]{2}{*}{ Isoxaben } & 0.8 & 8.3 & 6.0 & 2.5 & 0.8 & 4.0 & 4.0 & 9.0 & 8.5 \\
\hline & 1.1 & 9.0 & 6.5 & 0.0 & 0.0 & 4.5 & 4.0 & 9.5 & 8.3 \\
\hline Metolachlor & 4.5 & & & & & & & & \\
\hline + isoxaben & 0.8 & 8.3 & 7.3 & 1.0 & 1.0 & 4.3 & 4.8 & 6.8 & 5.8 \\
\hline Metolachlor & 4.5 & & & & & & & & \\
\hline + oxadiazon & 2.2 & 10.0 & 9.8 & 10.0 & 9.0 & 8.8 & 8.8 & 9.5 & 7.8 \\
\hline Metolachlor & 4.5 & & & & & & & & \\
\hline + oxadiazon & 4.5 & 10.0 & 8.8 & 10.0 & 9.5 & 9.5 & 8.5 & 8.0 & 4.5 \\
\hline $\operatorname{LSD}_{(0.05)}$ & & 1.9 & 2.7 & 2.3 & 2.2 & 3.0 & 3.1 & 1.9 & 2.7 \\
\hline
\end{tabular}


Table 5. Percent control of yellow nutsedge and eclipta with preemergence herbicides, 1990-91.

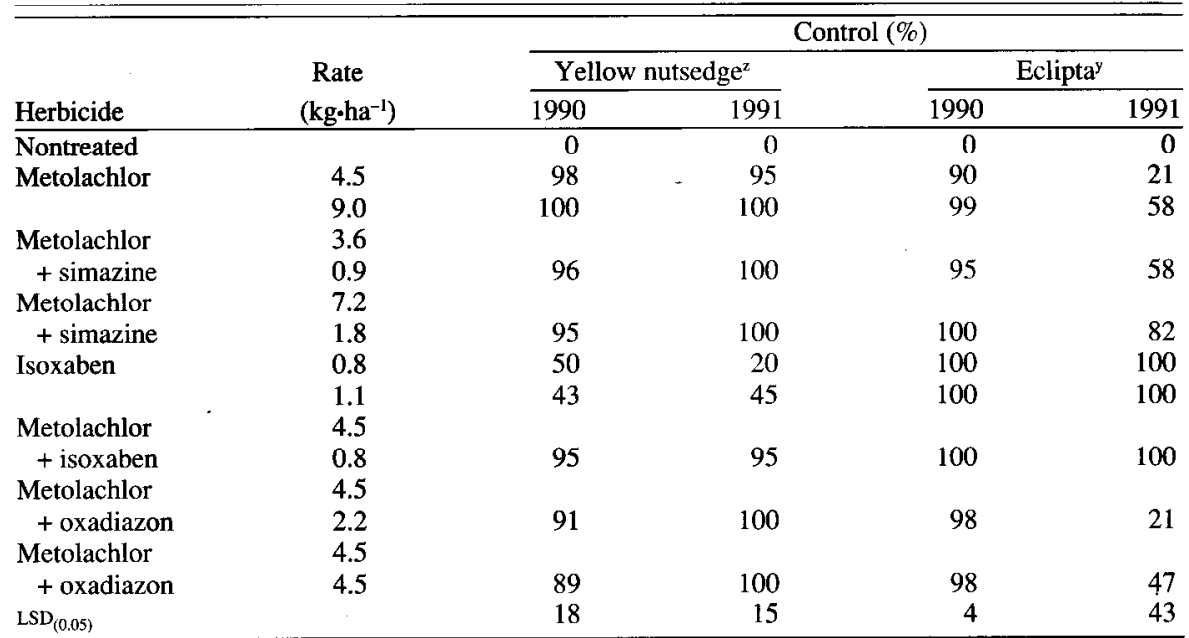

${ }^{2}$ Yellow nutsedge control ratings were recorded 7 and 6 weeks after herbicide application in 1990 and 1991 , respectively.

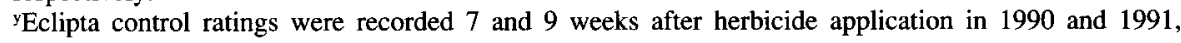
respectively.

coneflower compared to nontreated plots in the 1990-91 study (data not shown). Ox-eye daisy flowered less in plots treated with metolachlor plus either simazine or isoxaben. As in the 1990-91 study, flower counts in treated plots in the 1991-92 study seemed to be related to plant stand (Table 4). Flowers remained uninjured after metolachlor was applied to 14 spring flowering bulbs (Skroch et al., 1988), a result paralleling those observed for the wildflower species.

Treatments that contained metolachlor gave at least $89 \%$ yellow nutsedge control in 1990 and $95 \%$ to $100 \%$ control in 1991 (Table 5). Isoxaben did not control yellow nutsedge.
Treatments that contained isoxaben completely controlled eclipta in both studies. Metolachlor controlled eclipta acceptably in 1990 but not 1991. More frequent irrigation in 1991 may have reduced the duration of control provided by metolachlor.

This research demonstrated that metolachlor controls yellow nutsedge acceptably while being tolerated well by transplanted wildflowers. Further research is needed on alternative herbicides to combine with metolachlor for broader-spectrum weed control, since isoxaben and simazine caused unacceptable damage to the herbaceous perennials evaluated.

\section{Literature Cited}

Berchielli-Robertson, D.L., C.H. Gilliam, and D.C. Fare. 1990. Competitive effects of weeds on the growth of container-grown plants. HortScience 25:77-79.

Corley, W.L., J.W. Dobson, W.J. McLaurin, and A.E. Smith, Jr. 1989. Wildflower establishment methodology for Georgia and the Southeast. Proc. Southern Nurserymen's Assn. Res. Conf. 34:249-250.

Derr, J.F. and B.L. Appleton. 1992. Combinations of fabrics and films with organic and inorganic mulches for landscape weed control. Proc. Southern Nurserymen's Assn. Res. Conf. 37:291-293.

Dickens, R. 1992. Wildflower weed control. Grounds Maintenance (April):66, 68, 72.

Gaillitano, L.B. and W.A. Skroch. 1990. Weed management in wildflowers. Proc. Southern Nurserymen's Assn. Res. Conf. 35:250-251.

Gilliam, C.H., W.J. Foster, J.L. Adrain, and R.L. Shumack. 1990. A survey of weed control costs and strategies in container nursery production. J. Environ. Hort. 8:133-135.

Glaze, N.C., M. Singh, and S.C. Phatak. 1987. Ornamental tolerance to two methods of oxadiazon application. HortScience 22:265-268.

Norcini, J.G. and J.H. Aldrich. 1992. Spotted spurge control and phytotoxicity to daylily from preemergence herbicides. J. Environ. Hort. 10:14-17.

Porter, W.C. 1991. Response of container-grown herbaceous flowering perennials to isoxaben and isoxaben combinations. Proc. Southern Nurserymen's Assn. Res. Conf. 36:266-268.

Senesac, A. and J. Neal. 1992. Weed management guide for herbaceous ornamentals. Cornell Coop. Ext. Weed Facts 1.

Skroch, W.A., C.J. Catanzaro, and M.H. Yonce. 1990. Response of nine herbaceous flowering perennials to selected herbicides. J. Environ. Hort. 8:26-28.

Skroch, W.A., S.L. Warren, and A.A. DeHertogh. 1988. Phytotoxicity of herbicides to spring flowering bulbs. J. Environ. Hort. 6:109-113. 